\title{
Operational efficiency of leprosy clinics: a time-motion study
}

\author{
A KUMAR, P SIRUMBAN, K DURGAMBAL \\ \& S KALAIVANI
}

Division of Epidemiology and Statistics, Central Leprosy Teaching and Research Institute, Chingleput, Tamil Nadu, India 603001

\author{
Accepted for publication 17 December 1986
}

\begin{abstract}
Summary A Time-Motion Study was undertaken to estimate the time spent by leprosy patients in waiting as well as in utilization of various medical care services at monthly mobile leprosy clinics. On an average (mean $\pm \mathrm{SE}$ ), a patient spent $48 \pm 2 \cdot 6,42 \pm 4.8$ and $104 \pm 4 \cdot 2$ min each time at rural, urban and referral leprosy hospital clinics, respectively. More than $90 \%$ of this time was spent in waiting in queues for various clinic services. Based on the observations, the reorganization of a leprosy clinic to improve its operational efficiency is discussed in this communication.
\end{abstract}

\section{Introduction}

Leprosy programmes have made provisions to deliver the medical care services to leprosy patients through a network of mobile leprosy clinics, especially in high endemic areas. However, in most instances, the underequipped and inadequately organized clinics could not provide quality medical care to patients ${ }^{15,16}$ and ignored the psychological needs of individual patients, ${ }^{12}$ resulting in the failure of the present control strategies. The unsuitable and inconvenient leprosy clinic locations and timings were noted to be the important reasons for irregular and non-attendance at clinics by patients. ${ }^{1,2,14}$ Patients expressed their concern about the long time they had to spend at mobile leprosy clinics, especially in waiting for services, due to which a good proportion of them lost their wages for the day. ${ }^{6,7}$

Thus, the present Time-Motion Study was conducted with two objectives: 1, estimate the average time spent by the patients in waiting as well as utilization of various medical care services at monthly leprosy clinics; and 2, based on the above finding, to design a plan of action for organizing the leprosy clinics for an efficient delivery of medical care services, especially multidrug therapy (MDT), to the consumers. This is necessary for convenient and optimal utilization of these services by the consumers, which is the key to success of a leprosy eradication programme. 


\section{Material and method}

This study was carried out in monthly mobile leprosy clinics of 14 sectors (rural) of two Government Leprosy Control Units (GLCUs) operating in the Chingleput District of Tamil Nadu. For comparison the study also covered two headquarter (urban) weekly clinics of these two GLCUs; and the daily outpatient department (OPD) clinics of our Institute which is a referral leprosy hospital/institution. Each GLCU, covering a population of about 0.4 million, is divided into 20 sectors. The distribution of average population and leprosy patients in a sector in the study area is shown in Tables I (a) and (b).

The monthly mobile leprosy clinic in a sector was conducted at a central place under a tree by a team consisting of medical officer, nursing assistant, laboratory technician, pharmacist, nonmedical supervisor and the paramedical worker of the sector. As observed during the study, the team usually conducted only one sector clinic in a day between 8 am and 10.30 am and treated leprosy patients with dapsone alone.

For this study, two trained field wcrkers (FWs) together visited 28 monthly mobile leprosy clinics in 14 sectors (rural) and 4 weekly headquarter (urban) clinics of two GLCUs under the study, as well as 6 OPD clinics of our referral hospital. A total of 188 rural, 43 urban and 59 hospital OPD patients, who attended the above clinics, were randomly observed under this time-motion study. The characteristics of these patients are shown in Table 1(b).

Table 1(a). Distribution of population and leprosy patients (average) in a sector.

\begin{tabular}{|c|c|c|c|c|c|c|c|c|c|}
\hline \multirow[b]{3}{*}{ Population } & \multirow[b]{3}{*}{$\begin{array}{l}\text { No. of } \\
\text { villages }\end{array}$} & \multirow[b]{3}{*}{$\begin{array}{l}\text { Area } \\
\left(\mathrm{km}^{2}\right)\end{array}$} & \multirow{3}{*}{$\begin{array}{c}\text { Population } \\
\text { Density } \\
\text { per } \mathrm{km}^{2}\end{array}$} & \multicolumn{6}{|c|}{ Leprosy patients in a sector } \\
\hline & & & & \multicolumn{2}{|c|}{$\begin{array}{l}\text { Recorded } \\
\text { (known) }\end{array}$} & \multicolumn{2}{|c|}{$\begin{array}{c}\text { Registered } \\
\text { for Treatment }\end{array}$} & \multicolumn{2}{|c|}{$\begin{array}{l}\text { Attended } \\
\text { clinic }\end{array}$} \\
\hline & & & & Total & $\begin{array}{l}\text { Per } \\
\mathrm{km}^{2}\end{array}$ & Total & $\begin{array}{l}\text { Per } \\
\mathrm{km}^{2}\end{array}$ & Total & $\begin{array}{l}\text { Per } \\
\mathrm{km}^{2}\end{array}$ \\
\hline 24,348 & 13 & $43 \cdot 7$ & $557^{*}$ & $429 * *$ & $9 \cdot 8$ & $331^{* *}$ & $7 \cdot 6$ & $69^{* * *}$ & 1.7 \\
\hline
\end{tabular}

* As per 1981 census, the population density $/ \mathrm{km}^{2}$ of Tamil Nadu (TN) State and Chingleput District of Tamil Nadu (TN) were 371 and 457, respectively.

** A bout $35 \%$ of these recorded/registered cases were expected to be deleted from the list on account of their inactivity/treatment completion, once screening of cases for MDT was over.

*** Includes 10 cases who attended clinic by proxy, and 44 cases who had attended the clinics regularly in the past quarter. 
Table 1(b). Characteristics of leprosy patients in a sector.

\begin{tabular}{|c|c|c|c|}
\hline \multirow[b]{2}{*}{$\begin{array}{l}\text { Characteristics } \\
\text { of patients }\end{array}$} & \multicolumn{3}{|c|}{$\begin{array}{c}\text { A verage cases (percent) in a } \\
\text { sector }\end{array}$} \\
\hline & $\begin{array}{c}\text { Total } \\
\text { known }\end{array}$ & $\begin{array}{l}\text { Total } \\
\text { attended } \\
\text { clinic }\end{array}$ & $\begin{array}{l}\text { Total } \\
\text { included } \\
\text { in study* }\end{array}$ \\
\hline Male & $59 \cdot 0$ & $53 \cdot 6$ & $58 \cdot 3$ \\
\hline Children & $28 \cdot 0$ & $15 \cdot 9$ & $16 \cdot 6$ \\
\hline Multibacillary (MB) & $10 \cdot 8$ & $31 \cdot 8$ & $41 \cdot 6$ \\
\hline Deformed & $8 \cdot 4$ & $17 \cdot 7$ & $20 \cdot 8$ \\
\hline
\end{tabular}

* The 43 urban patients under study included $49 \%$ males, $14 \%$ children, $39 \% \mathrm{MB}$ and $14 \%$ deformed cases. Whereas 59 patients from hospital OPD were constituted by $54 \%$ males, $8 \%$ children, $79 \% \mathrm{MB}$ and $42 \%$ deformed cases.

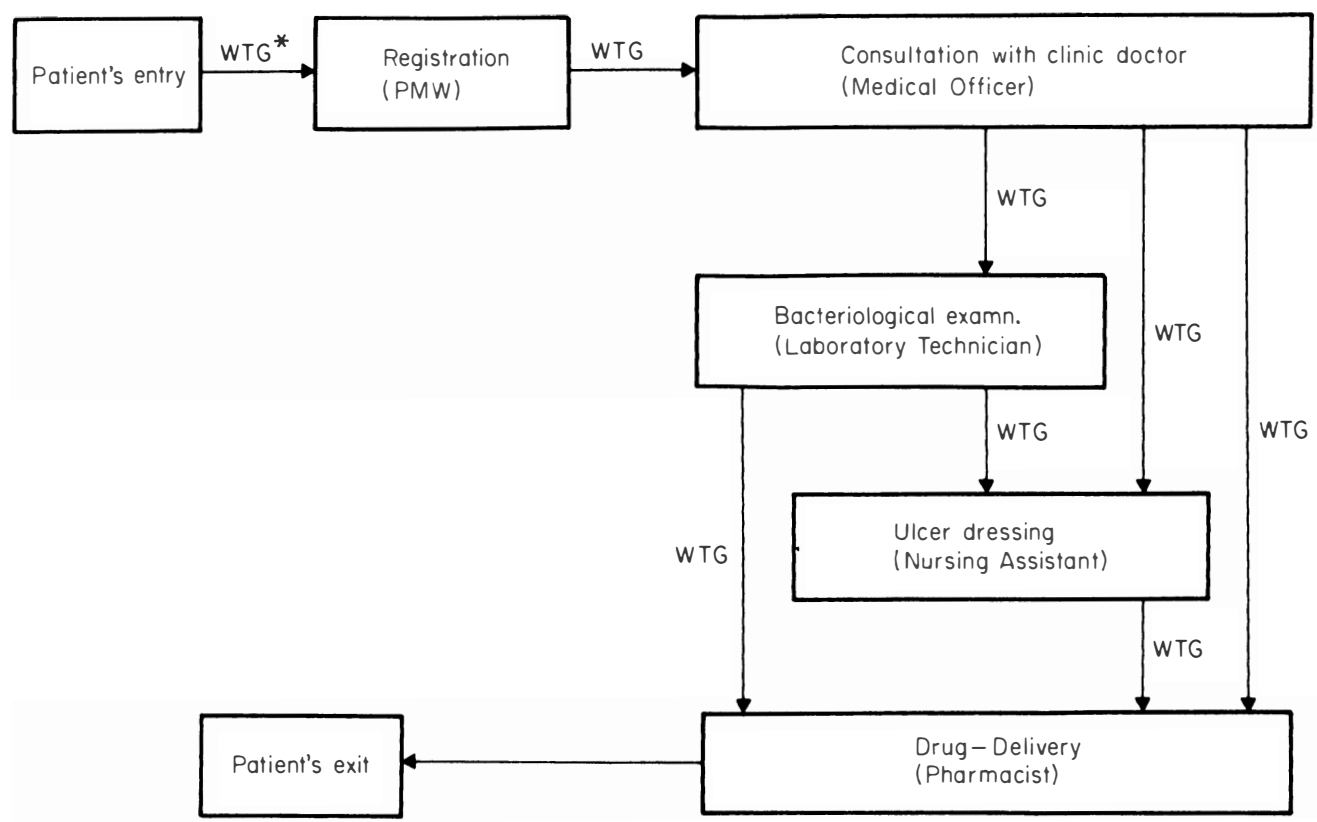

\footnotetext{
* Waiting in ' $Q$ '
}

Figure 1. Movement of patient in a sector clinic. 
During the visit to the leprosy clinics, each FW randomly and independently, spotted a patient while he/she entered into the clinic and followed the respective patient till he/she left the clinic, and with the help of a stopwatch recorded the time spent by the individual patients in waiting as well as in utilizing various medical care services at the clinic, as shown in Figure 1.

\section{Results/Observations}

\section{TIME SPENT BY PATIENTS AT LEPROSY CLINIC}

On an average a leprosy patient spent $42-48$ minutes at the urban/rural clinics and 104 minutes at the hospital OPD to get the medical care services for his/her illness (Table 2(a) and 2(b)).

Likewise, the distribution of time spent by a patient in actual utilization of various medical services at the leprosy clinic is shown in Table 2(c). The time spent by a patient in medical consultation at the referral hospital OPD was 4-5 times more than in rural/urban clinic. The reason for this could have been because a larger proportion of advanced (MB type) and deformed cases attended hospital OPD (Table 1(a)), whose examinations and recording, required more time.

No statistically significant difference was noticed between the time spent by a patient at clinic and his/her age, sex and disease-type, etc.

\section{Clinic ATtENDANCE By PATIENTS (RURAL) VS THE Distance BETWEEN THEIR RESIDENCES AND CLINIC LOCATIONS}

On an average, a patient travelled a distance of $3 \mathrm{~km}$ (one way) to attend clinic from his/her residence. No statistically significant relationship was noticed between clinic attendance and the distance of clinic location from the patient's residence (Table 3).

Table 2(a). Average time ( $\mathrm{min})$ spent by a patient at leprosy clinic.

\begin{tabular}{|c|c|c|c|}
\hline \multirow[b]{2}{*}{ Time spent } & \multicolumn{3}{|c|}{ Average time (mean $\pm \mathrm{SE})$ spent at clinic } \\
\hline & $\begin{array}{l}\text { Rural clinic } \\
(n=188)\end{array}$ & $\begin{array}{l}\text { Urban clinic } \\
\quad(n=43)\end{array}$ & $\begin{array}{c}\text { Referral hospital } \\
\text { OPD } \\
(n=59)\end{array}$ \\
\hline Waiting for services & $45 \cdot 8 \pm 2 \cdot 53$ & $37 \cdot 9 \pm 4 \cdot 53$ & $94 \cdot 2 \pm 4 \cdot 37$ \\
\hline Service utilization & $2 \cdot 4 \pm 0 \cdot 09$ & $3 \cdot 9 \pm 0 \cdot 44$ & $9 \cdot 5 \pm 0.74$ \\
\hline $\begin{array}{l}\text { Total time spent at clinic } \\
\text { (entry till exit) }\end{array}$ & $47 \cdot 9 \pm 2 \cdot 59$ & $42 \cdot 2 \pm 4 \cdot 76$ & $103 \cdot 6 \pm 4 \cdot 15$ \\
\hline
\end{tabular}

The distribution of time spent by patient in waiting for various medical services at leprosy clinic, is indicated in Table 2(a) 
Table 2(b). Distribution of average time (minutes) spent by a patient in waiting for medical services at leprosy clinic.

Average time (mean $\pm \mathrm{SE})$ spent in waiting

\begin{tabular}{|c|c|c|c|}
\hline Waiting for & Rural clinic & Urban clinic & Referral hospital OPD \\
\hline Clinic team to arrive & $19 \cdot 7 \pm 1 \cdot 51$ & $3 \cdot 7 \pm 0 \cdot 50$ & $14 \cdot 6 \pm 3 \cdot 32$ \\
\hline Registration at clinic & $6 \cdot 8 \pm 0 \cdot 39$ & $7 \cdot 4 \pm 0 \cdot 81$ & $4 \cdot 5 \pm 0.69$ \\
\hline Medical consultation & $17 \cdot 5 \pm 1 \cdot 13$ & $20 \cdot 9 \pm 1 \cdot 78$ & $36 \cdot 9 \pm 3 \cdot 07$ \\
\hline Bacteria examination* & $11 \cdot 0 \pm 0.74$ & $18 \cdot 4 \pm 1 \cdot 25$ & $12 \cdot 7 \pm 1 \cdot 00$ \\
\hline Ulcer dressing** & $\begin{array}{l}\text { No case with } \\
\text { ulcer studied }\end{array}$ & NA & $23 \cdot 0 \pm 2 \cdot 63$ \\
\hline Drug delivery & $0.6 \pm 0.08$ & $0.7 \pm 0.06$ & $0.7 \pm 0.08$ \\
\hline
\end{tabular}

* This average time is estimated for only those 5 urban, 13 Rural and 21 Hosp. OPD patients who were bacteriologically examined. No case included in study was referred for physiotherapy.

**Instead of dressing ulcer at clinic, the dressing material was provided to six rural patients for self dressing. However, ulcers of all patients were dressed by Nursing Assistant in Referral Hospital OPD.

NA, Not Applicable

Table 2(c). Distribution of Average Time spent by a patient in actual service utilisation at leprosy clinic.

Average time (mean $\pm \mathrm{SE})$ spent in service utilisation

\begin{tabular}{lccc}
\cline { 2 - 4 } Service utilised & Rural clinic & Urban clinic & Referral hospital OPD \\
\hline Registration & $1 \cdot 1 \pm 0 \cdot 04$ & $1 \cdot 4 \pm 0 \cdot 09$ & $0 \cdot 9 \pm 0 \cdot 08$ \\
Medical consultation* & $1 \cdot 3 \pm 0 \cdot 05$ & $1 \cdot 7 \pm 0 \cdot 17$ & $6 \cdot 1 \pm 0 \cdot 74$ \\
Bacteria examination** & $1 \cdot 5 \pm 0 \cdot 04$ & $2 \cdot 1 \pm 0 \cdot 09$ & $2 \cdot 4 \pm 0 \cdot 17$ \\
Ulcer dressing** & Not applicable & NA & $3 \cdot 9 \pm 0 \cdot 23$ \\
Drug receiving*** & $0 \cdot 6 \pm 0 \cdot 02$ & $0 \cdot 7 \pm 0 \cdot 06$ & $0 \cdot 7 \pm 0 \cdot 08$ \\
\hline
\end{tabular}

* Medical consultation includes History taking, examination and recording etc. of a patient by the clinic doctor.

** This average time is estimated only out of those cases who availed these services.

*** Drugs were issued unwrapped to patients invariably without instructions about the mode of intake \& regularity. 
Table 3. Distribution of leprosy patients in five sectors of study area according to the distance of clinic spot from their residences

\begin{tabular}{lcccccc}
\hline & \multicolumn{6}{c}{ Distance $(\mathrm{km})$ between residence \& clinic spot } \\
\cline { 2 - 7 } Cases & $\leqslant 2$ & $3-4$ & $5-6$ & $7-9$ & $\geqslant 10$ & Total \\
\hline Total known & 1215 & 501 & 311 & 283 & 44 & 2354 \\
& $(51.6 \%)$ & $(21 \cdot 3 \%)$ & $(13 \cdot 2 \%)$ & $(12.0 \%)$ & $(1.9 \%)$ & $(100 \%)$ \\
Registered for & 1018 & 446 & 264 & 249 & 34 & 2011 \\
treatment & $(55.6 \%)$ & $(22.2 \%)$ & $(13 \cdot 1 \%)$ & $(12.4 \%)$ & $(1.7 \%)$ & $(100 \%)$ \\
Attended & 197 & 55 & 47 & 34 & 10 & 343 \\
clinic & $(57 \cdot 4 \%)$ & $(16.0 \%)$ & $(13.7 \%)$ & $(9.9 \%)$ & $(2.9 \%)$ & $(100 \%)$ \\
& & & & & & \\
\end{tabular}

\section{Discussion}

The experience of patients with leprosy clinic services, revealed that on an average a patient had to cover a distance of $2 \cdot 1 \pm 2.5 \mathrm{~km}$ (one way) in $24 \pm 49$ min to reach the clinic, mostly by walking ( $83 \cdot 2 \%)$. A patient had spent $58 \cdot 9 \pm 32 \cdot 2 \mathrm{~min}$ at the clinic, of which two thirds was in waiting to receive the clinic services. The average man-days and wage losses to a patient due to monthly clinic attendance were estimated to be $0 \cdot 48 \pm 0 \cdot 49$ days and Rs. $2 \cdot 28 \pm 3 \cdot 06$, respectively. Almost all patients, especially aged and deformed ones, suggested that leprosy clinics should be conducted within $1.5 \mathrm{~km}$ from their residences between 6 and 8 am, so that their morning work would not be affected and they would not lose their wages. Availability and efficient delivery of comprehensive medical care through well organized and regularly conducted leprosy clinics, by considerate and sympathetic staff, was very much emphasized by the patients. ${ }^{6}$

'Poor staff compliance' accounts for falling short of essential goals in leprosy control programmes and perhaps not the patients' poor treatment compliance. ${ }^{4,8,9,10}$ It is therefore essential to efficiently organize and deliver medical care services through leprosy clinics with regard to the background of consumers, only then will these services be optimally utilized with good compliance by patients. ${ }^{1-3,5-7}$ Good treatment responses have been shown by patients where medical and paramedical personnel have shown personal interests in patients. ${ }^{11,13}$ Therefore considering the needs of patients that leprosy clinics be conducted within $1.5 \mathrm{~km}$ from their residences at convenient timings, we should now think of re-organizing existing leprosy clinics to make them more acceptable to the consumers.

As shown in Table 1(a), one study sector had approximately 275 leprosy patients, including $10 \% \mathrm{MB}$ cases, eligible for MDT. These cases were distributed in $44 \mathrm{~km}^{2}$ area of the sector, i.e. 6 cases per $\mathrm{km}^{2}$. If one is to conduct sector leprosy 
clinics so that patients do not have to walk more than $1.5 \mathrm{~km}$ to attend, then one sector would need to have six treatment delivery points (TDP), each TDP covering an area of about $7 \mathrm{~km}^{2}$ and approximately 42 patients for treatment (Figure 2). If sector PMW could motivate and ensure at least $75 \%$ of the patients for regular clinic attendance treatments, then the team will have to spend about 45 $\min (31 \times 1.3 \mathrm{~min})$ to conduct clinic at each TDP.

The work load of a medical officer (MO) and his team of one GLCU covering 20 sectors means they have to conduct the clinics at all 6 TDPs of one sector on the same day between 6 and $11 \mathrm{am}$. Admittedly, they do have of course a wellmaintained vehicle, but by the time the team reached the 5th and 6th TDPs, around $9.30 \mathrm{am}$, it is likely that patients' availability may reduce, which could be effectively taken care of if the patients are properly educated and convinced to attend clinic by the field worker concerned. There cannot be a better way of motivating patients than providing the quality of medical care services efficiently by considerate and sympathetic staff, as per the satisfaction and expectation of patients.

This approach of establishing six TDPs in a sector may: 1, reduce the distance and time spent on travel by the patients to reach the clinic; 2 , help the team to cope efficiently with uniformly distributed caseloads at each TDP; 3 , reduce the total time spent by patients at clinic; and 4 , thus motivate the patients for regular clinic attendance and treatment. Needless to say the clinic team should observe

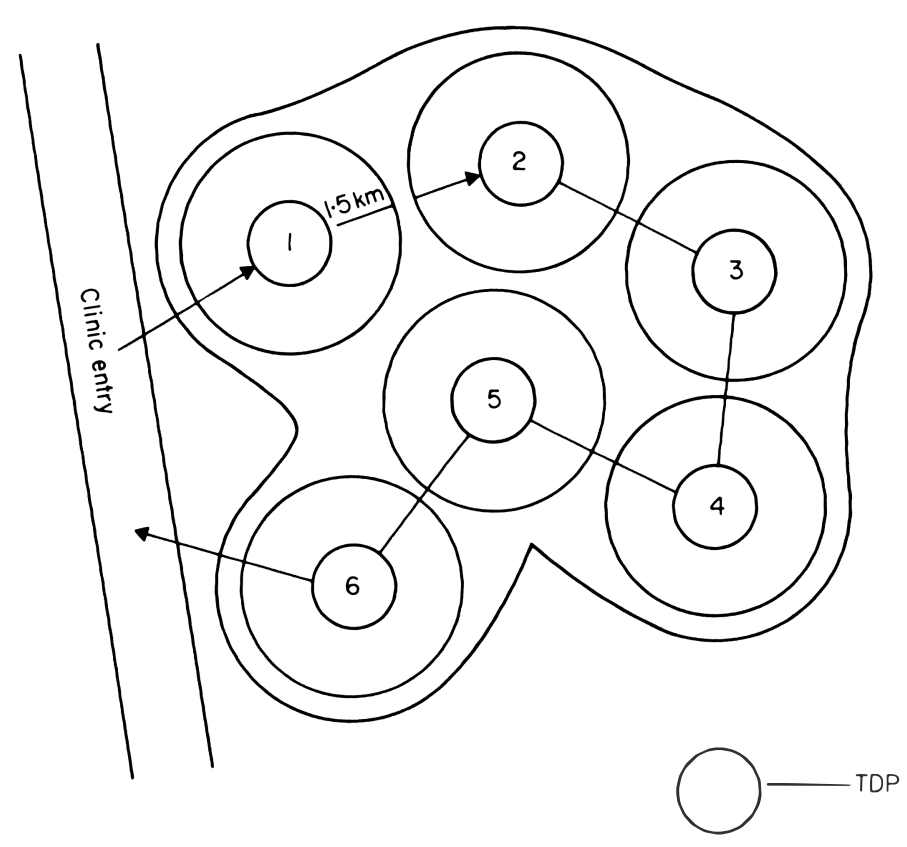

Figure 2. Organization of six TDP's in a sector. 
punctuality and regularity in conducting clinics, then only one team would be able to cover all the six TDPs in a day. Moreover, punctuality on the part of the team will reduce by $19 \mathrm{~min}$ the time which patients spend in waiting due to the late arrival of the team (Table 2(b)). In this way the team could save patients $60 \%$ of the time spent waiting for services at the clinic. The remaining waiting period, which is inevitable, can advantageously be utilized by involving patients; 1 , in educating them about their disease and treatment related matters; 2, demonstration of simple physiotherapy techniques, care of anaesthetic hands/feet and ulcer, mode of drug administration; and 3, in discussing the solutions to patients' common health problems as a result of their disease or otherwise, etc. Valuable efforts of this kind are in little evidence in the medical care delivery programmes and various, easily available, simple and educative techniques could be satisfactorily used by the team for this purpose.

Though the observations gathered through the present piece of work may be more valid for the study area, similar attempts could be made in different situations in order to reorganize the medical care delivery system, as per the local conditions. In continuation another operational study is being planned to observe: 1, the quality of medical care services being delivered by the team to patients through leprosy clinics; 2 , factors influencing the operational efficiency of the clinic and the team; and 3, to study the extra inputs (resources) required to improve efficiency of the medical care delivery system.

\section{Acknowledgments}

This operational research project was carried out under the 'ICMR Unit for special studies in Leprosy' attached to our Institute. Authors are grateful for the kind cooperation extended by Dr S Natesan Deputy Director of Medical Services (leprosy), Dr Gopalakrishnan Medical Officer of GLCU Kancheepuram, Dr Panneerselvam Medical Officer of GLCU Tambaram, Government of Tamil $\mathrm{Nadu}$. The secretarial assistance of Kum Anusuya and statistical assistance of $\mathrm{Mr}$ R Perumal, are also thankfully acknowledged.

\section{References}

1 Kumar A, Anbalagan M. Illness and service utilization behaviours of leprosy patients. Lepr Ind, 1982; 54: 338-47.

2 Kumar A, Sivaprasad N, Anbalagan M, Thangavel N, Durgambal K. Utilization of medical agencies and treatment compliance by urban (Madras) leprosy patients. Lepr Ind, 1983; 55: 322-32.

${ }^{3}$ Kumar A, Balakrishnan S. Operational study to monitor the regularity of Dapsone intake by leprosy out-patients. Lepr Ind, 1983; 55: 521-7.

${ }^{4}$ Kumar A, Sivaprasad N, Sirumban P, Anbalagan M, Durgambal K. Community awareness 
about leprosy and participation in National Leprosy Control Programme. Lepr Ind, 1983; 55: 701-11.

${ }^{5}$ Kumar A. Treatment compliance by leprosy out-patients and its monitoring under field conditions. Ind J Lepr, 1984; 56: 313-18.

${ }^{6}$ Kumar A, Thangavel N, Durgambal K, Sirumban P. Medical care delivery through leprosy clinics - Consumer's perception, experience and suggestions. Ind J Lepr, 1985; 57: 845-61.

7 Kumar A, Thangavel N, Durgambal K, Sirumban P. Man-days and wages loss to patients due to leprosy clinic and hospital attendance. NLO Bull, 1985; October-December, 65-7.

${ }^{8}$ Imam B, Leprosy Care-patients' expectations and experience - a case study in western province, Kenya, Royal Tropical Institute, Amsterdam (Quoted by Bijileveld 1982), 1977.

9 Imam B. Why say leprosy patients are ashamed or lazy? Sasakawa report on 3rd International Workshop on leprosy control in Asia, held in Japan, 1980.

10 Imam B, In reality: a medical arthropologist's presentations about the viability of leprosy control within primary health care. Lepr Rev, 1982; 53: 181-92.

1 Faria E. When can a patient stop treatment? The Star, 1978; 37: 10.

12 Jagadisan TN. The human problem of leprosy control. The Star, 1978; 38: 10-11.

$13 \mathrm{Kim}$ D. Case finding and case holding methodologies in leprosy control in Korea. Sasakawa Report on 3rd International Workshop on leprosy control in Asia, held in Japan, 1980; 71-8.

14 Mathews CME, Jesudasan M. A leprosy health education project. Int J Lepr, 1978; 46: 414-25.

15 Ramasoota T. Case finding and case holding methodologies in leprosy control in Thailand. Sasakawa report on 3rd International Workshop on Leprosy control in Asia, Japan, 1980; 505.

16 Sameul NM. Case finding and case holding methodologies in leprosy control in Nepal. Sasakawa Report on 3rd International Workshop in leprosy control in Asia, Japan, 1980; 7-16.

TEACHING MATERIALS AND SERVICES

\section{TALMILEP}

A meeting of TALMILEP was held at the Association Francaise Raoul Follereau in Paris in March 1987 to consider: teaching material in French language; the support of the Ciba-Geigy Leprosy Fund for the TALMILEP budget in the current year; working procedures; the translation of existing material into other languages and the development of new material. To quote from the brochure: 'TALMILEP has undertaken to stimulate, facilitate and coordinate efforts to provide and distribute teaching and learning materials in leprosy, worldwide, and to devise the most appropriate mechanisms for achieving this within ILEP.'

Its main aims are:

To coordinate efforts for providing all categories of health workers involved in leprosy control and patient care, worldwide, with teaching and learning materials.

To promote the development of high quality materials by ILEP member associations, adequately covering all relevant subject aspects, and avoiding unnecessary duplication of work.

To encourage the local production of teaching and learning materials by people in their own countries.

To set up active distribution networks and thus ensure worldwide availability of materials.

To make information about teaching and learning materials generally available.

This joint project by various members of the International Federation of Anti-Leprosy Associations (ILEP) is undoubtedly making progress. Virtually for the first time, there is now in existence a mechanism for the development, assessment, revision, printing and distribution of suitable health-learning material, in various languages, for leprosy. Further enquiries to: The Secretary TALM ILEP, Ms K Rössler, German Leprosy Relief Association, PO Box 348, D-8700, Wurzburg, West Germany. 


\section{Health Education in Leprosy Work; a manual for health workers}

This is a manual of 96 pages, written by Dr Luc G Van Parijs, published by the Association Francaise Raoul Follereau, Paris, France, with copyright by ILEP, 234 Blythe Road, London W14 OHJ, printed for The Leprosy Mission International (TLMI), 50 Portland Place, London WIN 3DG. It is available in English and French. This very comprehensive manual also has a bibliography and questionnaire.

\section{The Leprosy Mission International, London; teaching and learning materials}

We remind readers that a very comprehensive range of written materials for teaching and learning in leprosy, to suit various grades of leprosy worker, is available on application to: Teaching and Learning Materials, The Leprosy Mission (International), 50 Portland Place, London WIN 3DG. Some items are free; others have to be paid for. There is a most valuable checklist indicating which materials are suitable for supervisors, senior health workers, laboratory technicians, physiotherapy technicians, medical students and surgeons.

\section{Teaching Aids at Low Cost (TALC), London}

In addition to slide-text sets of colour transparencies on clinical leprosy in children and histopathology, previously described in this journal, TALC now carries a new set by Dr Grace Warren (The Leprosy Mission International) on 'Leprosy Lesions in Skins of Different Colours'. In association with Miss Jo Tomlan, Overseas Missionary Fellowship, Thailand, Dr Warren has also produced a set on 'Care of the Nerve Damaged Limb'. The excellence (and low cost) of these sets from TALC can hardly be overemphasized; it is doubtful if any other agency produces material of such good quality, by experts in their field, at such a low price. Further details of these new sets, the two previous ones on leprosy, and of dozens of othersets on mainly tropical health problems, are available from Teaching Aids at Low Cost, PO Box 49, St Albans, Herts ALI 4AX, England.

\section{Colour posters for health manpower training}

The International Green Cross in collaboration with WHO has produced a second series of six colour posters (in English only) for use in the education and training of health workers, especially auxiliaries, in developing countries. They can also be used for health education purposes in secondary schools. These posters follow those prepared in 1980 on the stomach, lungs, liver, eye, ear and teeth.

The present set deals with the nervous system, the skeleton and muscles, lymphatic and blood vessels, reproduction, the breast, and glaucoma. The first five of these posters have been sent to the national project managers of the WHO/UNDP Interregional Health Learning Materials Programme and to UNICEF for distribution. Small quantities may also be obtained, free of charge, from the Division of Health Manpower Development, World Health Organization, 1211 Geneva 27, Switzerland. As for the poster on glaucoma, a limited number are available from WHO's Programme on the Prevention of Blindness in Geneva.

\section{Bacteriological Index (BI) Charts for Leprosy Smears}

This chart, previously published in this journal $(57, \mathrm{p}$ 82) and also reproduced in various teaching-learning documents during the past year, was submitted to Dr NK Shah, Director, Prevention and Control of Diseases, WHO, Regional Office for South East Asia, New Delhi. He has now kindly written to say that 40,000 copies have been distributed to all leprosy institutions in India. WHO is also arranging to send 200 copies to each of the 9 countries in the South East Asia Region in which leprosy is endemic.

There is no copyright or other restriction; copies are available from the Editorial Office of Leprosy Review.

\section{Questions and Answers on the Implementation of Multiple Drug Therapy (MDT) for Leprosy \\ This booklet of 35 pages is available in English, and now also in Portuguese, from OXFAM, 274 Banbury Road, Oxford OX2 7DZ, England. Price $£ 1.50$ per copy.}

\section{Diploma in Health Education in Developing Countries.}

The University of Leeds in the UK offers a 'Diploma in Health Education in Developing Countries'. This ninemonth training course is designed for experienced field personnel and provides both theoretical and practical aspects of education and communication methods applied to health, nutrition and population programmes. Course participants specialize in these fields within an overall context of health education and primary health care.

Further information:

Dr John Hubley

Department of Health Education

Leeds Polytechnic

Calverley Street

Leeds LSI 3HE, UK. 